\title{
Protein Enrichment of Sweet Potato Residue with Amylolytic Yeasts by Solid-State Fermentation
}

\author{
Shang-Shyng Yang \\ Department of Agricultural Chemistry, National Taiwan University, Taipei, \\ Taiwan, Republic of China
}

Accepted for publication September 18, 1987

\begin{abstract}
Starchy agricultural wastes were inoculated with amylolytic yeasts for protein enrichment by solid-state fermentation. The moisture content of substrate was $65-69 \%$, and water activity was equivalent to $0.98-0.99$. The optimum conditions for protein enrichment were initial moisture content $65 \%$, initial $\mathrm{pH} 4.5$, a 1:1 mixture of ammonium sulfate and urea was incrementally added to the ferment with $1 \%$ added at zero time, $1 \%$ added at $24 h$, and $0.5 \%$ added at $48 \mathrm{~h}$, and incubation with amylolytic yeasts $\left(1.0 \times 10^{10} / 100 \mathrm{~g}\right.$ substrate $)$ at $30^{\circ} \mathrm{C}$ for $2-3$ days. The final product contained $16.11-$ $20.82 \%$ protein.
\end{abstract}

\section{INTRODUCTION}

The protein demands for direct human consumption and animal feeding will inevitably increase in the next two decades. ' In 1984, Taiwan imported $1.34 \times 10^{6}$ tons soy beans from the United States, which cost $4.38 \times 10^{8}$ U.S. dollars. ${ }^{2}$ Consequently, it is urgent to develop local protein resources with renewable raw materials for animal feed. Considering the cost, a starchy material such as the sweet potato might be a good substrate for protein enrichment for two reasons. First, Taiwan has a large cultivation area $(27,791 \mathrm{ha})$ for sweet potatoes, and the annual production is usually very high, e.g., $4.24 \times 10^{5}$ tons in 1984 . Second, the sweet potato can be easily converted to biomass by a great number of fast-growing microorganisms. ${ }^{1,3}$

In order to be economically competitive, the bioconversion of starchy materials into protein should be able to be performed at the rural level. Solid-state fermentations can achieve this purpose by reducing the cost of growing microorganisms, improving the in vitro rumen digestibility, and increasing the protein and fat contents of starchy or cellulosic materials. ${ }^{1,4,5}$ In this article we report our studies on the possibilities of enriching the protein content of sweet potato residue by the solid-state fermentation process.

\section{MATERIALS AND METHODS}

\section{Sweet Potato Residue}

Sweet potato residue was purchased from the local market in Taiwan. It contains $14.0-16.1 \%$ moisture, $2.32 \%$ crude protein, $3.6 \%$ ash, $18.1 \%$ crude fiber, and $65.4 \%$ carbohydrate.

\section{Culture Media and Culture Conditions}

\section{Liquid Medium}

The tested organism was cultivated in liquid shaking culture at $30^{\circ} \mathrm{C}$ for 2 days. Soluble starch $(0.4 \%)$ and yeast extract $(0.2 \%)$ were used as the carbon and nitrogen sources, respectively.

\section{Solid-State Medium}

Sweet potato residue $(100 \mathrm{~g})$, nitrogen source $\left[\left(\mathrm{NH}_{4}\right)_{2} \mathrm{SO}_{4}\right.$, urea, or their mixture] $(1-2.5 \mathrm{~g}), \mathrm{KH}_{2} \mathrm{PO}_{4}(\mathrm{lg})$, and yeast cells (or spores of Aspergillus) $\left(1.0 \times 10^{9}\right)$ were mixed thoroughly, and the substrate was adjusted to $\mathrm{pH} 4.5$ with $\mathrm{H}_{2} \mathrm{SO}_{4}$. The solid-state medium was incubated at $30^{\circ} \mathrm{C}$ for 2-3 days.

\section{Tested Organism}

Pichia burtonii CBS 6141, Lipomyces starkeyi CBS 1804, and Schwanniomyces castllii CBS 2863 were provided by P. Galzy, ENSA, France. Saccharomyces diastaticus IFO 1015 STA 1 (D), S. diastaticus IFO 1046 STA 1, STA 2 (D), S. diastaticus ATCC $28339 \propto$ mel 1 DEX MAL, SUC (H), Saccharomyces sp. IFO 1426 (D), S. cerevisiae IOB $5162 \propto$ leu 2, ura 1 STA $1(\mathrm{H})$ were provided by W. H. Wang, Research Institute for Wines, Taiwan Tobacco and Wine Monopoly Bureau. Aspergillus niger NTU-AM-1, $A$. niger NTU-AM-2, and $A$. niger NTUAM-3 were obtained from the collections of our laboratory. All of them have amylolytic activities.

\section{Chemical Analysis}

\section{Moisture Content}

Fermented sweet potato residue was dried at $60^{\circ} \mathrm{C}$ under vacuum for $8-12 \mathrm{~h}$ until its weight remained constant. The 
weight difference after drying was considered the moisture content.

\section{Water-Holding Capacity}

Sweet potato residue was soaked in water at $20^{\circ} \mathrm{C}$ for $24 \mathrm{~h}$ and centrifugated at $14,000 \mathrm{~g}$ for $1 \mathrm{~h}$, the supernatant was discarded, and the amount of moisture of the residual pellet was determined as water-holding capacity. ${ }^{6}$

\section{Bulk Density}

The dry weight or wet weight of sweet potato residue per unit volume $\left(1 \mathrm{~cm}^{3}\right)$ was the bulk density in dry weight or wet weight, respectively. ${ }^{7}$

\section{Water Activity}

Samples with different moisture contents were placed in a sealed container at $25^{\circ} \mathrm{C}$, and water activity was determined by a hygrometer. ${ }^{8}$

\section{Soluble Nitrogen}

Sample was extracted with 5 times volume of distilled water and shaken for $20 \mathrm{~min}$. Soluble nitrogen was determined directly by the Kjeldahl method.

\section{Protein Content}

Protein content was calculated by 6.25 times the difference between total nitrogen and soluble nitrogen of sample.

\section{Total Nitrogen, Total Sugar, Ash, and Crude Fiber Contents}

Total nitrogen was determined by the Kjeldahl method, total sugar was determined by the phenol- $\mathrm{H}_{2} \mathrm{SO}_{4}$ method, crude fiber was determined by ash-free residue digested with $1.25 \% \mathrm{NaOH}$ and $1.25 \% \mathrm{H}_{2} \mathrm{SO}_{4}$, and ash content was determined by heating at $550-600^{\circ} \mathrm{C}$ for $5 \mathrm{~h}^{9}{ }^{9}$

\section{RESULTS}

\section{Physical Properties of Sweet Potato Residue}

The water-holding capacity of sweet potato residue was $72 \%$. The moisture content of the substrate was between 65 and $69 \%$, which was lower than the water-holding capacity. The water activity of the substrate was $0.98-0.99$. Consequently, the substrate was suitable for the growth of aerobic microbes to enrich the protein content.

The relationship between the bulk density and moisture content of sweet potato residue is shown in Figure 1. The bulk density in wet weight increased with the increase of moisture content, but the bulk density in dry weight was

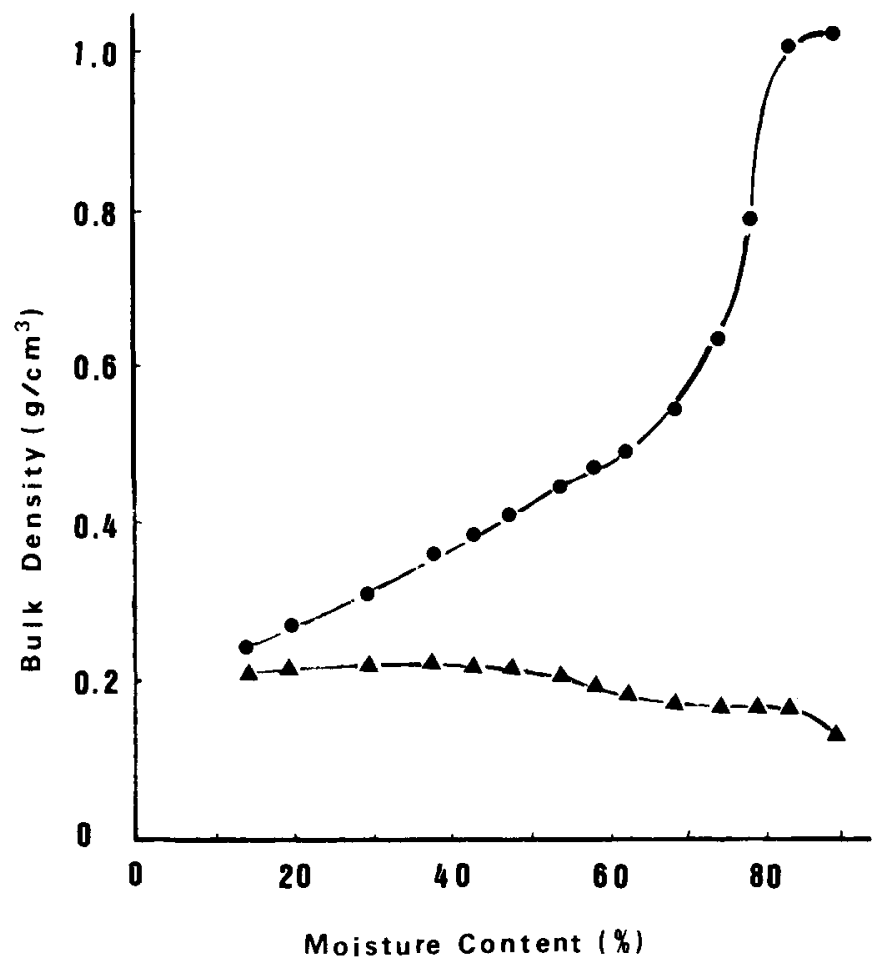

Figure 1. Bulk density of sweet potato residue at different moisture contents: $\longrightarrow$, wet-weight basis; $\longrightarrow$, dry-weight basis.

the reverse. The bulk densities were $0.51-0.58$ and $0.18-$ $0.19 \mathrm{~g} / \mathrm{cm}^{3}$ in wet weight and dry weight, respectively.

\section{Solid-State Fermentation}

A home-made column fermentor $(6.3 \mathrm{~cm}$ i.d., $6.8 \mathrm{~cm}$ o.d., height $70 \mathrm{~cm}$ ) surrounded by a water jacket was used in this study. During the fermentation, the medium was agitated once a day.

\section{Initial Moisture Content}

Pichia burtonii CBS 6141 was inoculated into the solidstate medium with the initial moisture ranging from 50 to $74 \%$ and incubated at $30^{\circ} \mathrm{C}$ for 3 days. After culture, it was found that the moisture content of the final product increased $4.0-11.5 \%$. The optimum condition of the maximum value of protein enrichment $(4.26 \%$ on a dry-weight basis) was at the initial moisture content of $65 \%$ and final moisture content of $69 \%$.

If the initial $\mathrm{pH}$ of the substrate was 4.5 , then the final $\mathrm{pH}$ of the product lay in the range of 3.5-4.9. Due to such low $\mathrm{pH}$ values in the solid-state fermentation process, the bacterial contamination will be minimized. After fermentation, the bacterial count was only about $10^{3} \mathrm{~g}^{-1}$ of dryweight substrate. The bulk density in wet weight increased progressively during the fermentation. The final bulk density increased $65-210 \%$ of initial bulk density. The initial and final bulk densities for the highest protein enrichment of sweet potato residue were 0.56 and $1.32 \mathrm{~g} / \mathrm{cm}^{3}$, respectively. 


\section{Selection of Tested Organisms}

The results of protein enrichment with different amylolytic organisms are shown in Table I. Protein enrichment with Saccharomyces sp. IFO 1426 (D), S. diastaticus IFO 1046 (D), and $A$. niger NTU-AM-1 was about 5\%; that with S. diastaticus ATCC $28339(\mathrm{H})$, P. burtonii CBS 6141, A. niger NTU-AM-2, and A. niger NTU-AM-3 was between 3.0 and $3.6 \%$; and that with $S$. diastaticus IFO 1015 (D), S. cerevisiae IOB 5162, and $S$. castellii CBS 2863 was less than $3.0 \%$. Therefore, Saccharomyces sp. IFO 1426 (D) was selected for further study.

\section{Nitrogen Source}

The different effects of protein enrichment of sweet potato residue when $\left(\mathrm{NH}_{4}\right)_{2} \mathrm{SO}_{4}$, urea, $\mathrm{NH}_{4} \mathrm{NO}_{3}$, or a mixture of $\left(\mathrm{NH}_{4}\right)_{2} \mathrm{SO}_{4}$ and urea was used as the nitrogen source are shown in Table II. A 1:1 mixture of ammonium sulfate and urea as nitrogen source gave rise to the highest protein enrichment (14.04\%), a $2: 1$ mixture the second $(13.75 \%)$, and a $3: 1$ mixture the third $(12.03 \%)$. However, if $\left(\mathrm{NH}_{4}\right)_{2} \mathrm{SO}_{4}, \mathrm{NH}_{4} \mathrm{NO}_{3}$, or urea was used solely as the nitrogen source, the protein enrichment was only 4.75$6.65 \%$. In addition, using the mixture of ammonium sul-

Table I. Protein enrichment with different microorganisms by solid-state fermentation.

\begin{tabular}{|c|c|c|c|c|c|c|c|c|}
\hline $\begin{array}{l}\text { Tested } \\
\text { strain }\end{array}$ & $\begin{array}{c}\text { Initial } \\
\text { moisture (\%) }\end{array}$ & $\begin{array}{c}\text { Final } \\
\text { moisture (\%) }\end{array}$ & $\begin{array}{c}\text { Protein } \\
\text { enrichment }(\mathrm{mg} / \mathrm{g})\end{array}$ & $\begin{array}{c}\text { Initial } \\
\mathrm{pH}\end{array}$ & $\begin{array}{l}\text { Final } \\
\mathrm{pH}\end{array}$ & $\begin{array}{c}\text { Total } \\
\text { carbohydrate } \\
\text { decrease }(\mathrm{mg} / \mathrm{g})\end{array}$ & $\begin{array}{l}\text { Weight } \\
\text { loss }(\%)\end{array}$ & $\begin{array}{l}\text { Bulk density } \\
\text { increase (\%) }\end{array}$ \\
\hline \multicolumn{9}{|l|}{ Saccharomyces } \\
\hline sp. IFO 1426 & 66.4 & 67.6 & 50.5 & 4.50 & 3.52 & 508.5 & 14.12 & 3.00 \\
\hline \multicolumn{9}{|l|}{$\begin{array}{l}\text { Saccharomyces } \\
\text { diastaticus }\end{array}$} \\
\hline IFO 1046 & 66.5 & 69.1 & 51.0 & 4.75 & 2.95 & 541.0 & 14.31 & 3.56 \\
\hline \multicolumn{9}{|l|}{ S. diastaticus } \\
\hline IFO 1015 & 66.0 & 67.5 & 26.7 & 4.86 & 2.97 & 593.5 & 10.88 & 2.29 \\
\hline \multicolumn{9}{|l|}{ S. diastaticus } \\
\hline ATCC 28339 & 66.8 & 69.0 & 30.0 & 4.82 & 3.90 & 540.0 & 11.60 & 5.83 \\
\hline \multicolumn{9}{|l|}{ Schwanniomyces } \\
\hline 2863 & 65.5 & 67.0 & 23.5 & 4.90 & 2.90 & 248.0 & 4.10 & 14.53 \\
\hline \multicolumn{9}{|l|}{ Pichia burtonii } \\
\hline CBS 6141 & 65.6 & 67.5 & 29.1 & 4.60 & 2.81 & 302.0 & 4.65 & 5.25 \\
\hline \multicolumn{9}{|l|}{ S. cerevisiae } \\
\hline IOB 5162 & 65.6 & 68.9 & 21.1 & 4.60 & 3.40 & 444.3 & 4.08 & 6.12 \\
\hline \multicolumn{9}{|l|}{ Aspergillus niger } \\
\hline NTU-AM-1 & 70.8 & 75.6 & 48.0 & 3.64 & 3.34 & 490.0 & 17.36 & 8.00 \\
\hline \multicolumn{9}{|l|}{ A. niger } \\
\hline NTU-AM-2 & 74.5 & 77.7 & 36.0 & 4.01 & 2.92 & 461.2 & 13.99 & 13.64 \\
\hline \multicolumn{9}{|l|}{ A. niger } \\
\hline NTU-AM-3 & 70.6 & 71.3 & 30.1 & 4.10 & 3.28 & 493.0 & 10.54 & 8.86 \\
\hline
\end{tabular}

Table 11. Effect of nitrogen source on protein enrichment of sweet potato residue. ${ }^{\mathrm{a}}$

\begin{tabular}{|c|c|c|c|c|c|c|c|}
\hline \multirow[b]{2}{*}{ Item } & \multirow{2}{*}{$\begin{array}{l}\text { Fermentation } \\
\text { time (h) }\end{array}$} & \multirow[b]{2}{*}{$\left(\mathrm{NH}_{4}\right)_{2} \mathrm{SO}_{4}$} & \multirow[b]{2}{*}{ Urea } & \multirow[b]{2}{*}{$\mathrm{NH}_{4} \mathrm{NO}_{3}$} & \multicolumn{3}{|c|}{ Ratio of $\left(\mathrm{NH}_{4}\right)_{2} \mathrm{SO}_{4}$ to urea } \\
\hline & & & & & $1: 1$ & $2: 1$ & $3: 1$ \\
\hline \multirow{4}{*}{$\begin{array}{l}\text { Moisture } \\
\text { content }(\%)\end{array}$} & 0 & 68.69 & 71.04 & 69.57 & 70.34 & 69.68 & 69.96 \\
\hline & 24 & 69.19 & 72.35 & 69.39 & 71.07 & 70.70 & 70.60 \\
\hline & 48 & 70.09 & 74.95 & 69.71 & 70.21 & 70.90 & 70.93 \\
\hline & 72 & 69.62 & 75.46 & 70.56 & 69.94 & 70.52 & 71.10 \\
\hline \multirow{4}{*}{$\begin{array}{l}\text { Protein } \\
\quad \text { content }(\%)\end{array}$} & 0 & 6.08 & 6.05 & 6.05 & 6.01 & 5.94 & 5.99 \\
\hline & 24 & 8.12 & 9.72 & 8.37 & 9.52 & 8.72 & 8.64 \\
\hline & 48 & 9.58 & 10.12 & 9.24 & 12.01 & 10.13 & 9.87 \\
\hline & 72 & 11.62 & 12.70 & 10.75 & 14.04 & 13.75 & 12.03 \\
\hline \multirow[t]{4}{*}{$\mathrm{pH}$} & 0 & 4.7 & 4.7 & 4.7 & 4.7 & 4.7 & 4.7 \\
\hline & 24 & 3.2 & 7.5 & 3.3 & 3.5 & 3.3 & 3.3 \\
\hline & 48 & 3.1 & 8.1 & 3.5 & 3.5 & 3.5 & 3.5 \\
\hline & 72 & 3.1 & 7.9 & 3.5 & 3.5 & 3.8 & 3.8 \\
\hline \multirow{4}{*}{$\begin{array}{l}\text { Ash content } \\
\text { (\%) }\end{array}$} & 0 & 3.52 & 3.43 & 3.41 & 3.56 & 3.61 & 3.59 \\
\hline & 24 & 3.55 & 3.67 & 3.53 & 3.73 & 3.77 & 3.83 \\
\hline & 48 & 3.65 & 3.98 & 4.02 & 3.99 & 3.95 & 4.04 \\
\hline & 72 & 4.24 & 4.26 & 4.18 & 4.37 & 4.37 & 4.37 \\
\hline
\end{tabular}

${ }^{a}$ Fermentation conditions: each gram of substrate inoculated with Saccharomyces sp. IFO 1426 , $4 \times 10^{7}$ cells, supplemented with $2.5 \%$ nitrogen source and incubated at $30^{\circ} \mathrm{C}$. 
fate and urea from a $1: 1$ to a $3: 1$ ratio as the nitrogen source could prevent the $\mathrm{pH}$ decline during the fermentation.

The weight of substrate dropped significantly during the fermentation. The values were between 10.54 and $17.36 \%$ in 3 days incubation at $30^{\circ} \mathrm{C}$. However, this result was consistent with the theoretical value of increasing the ash content of substrate.

\section{Method of Nitrogen Addition}

The effect of nitrogen addition on the protein enrichment of sweet potato residue is shown in Table III. A $1: 1$ or 2:1 mixture of ammonium sulfate and urea incrementally added to the ferment with $1 \%$ added at zero time, $1 \%$ added at $24 \mathrm{~h}$, and $0.5 \%$ added at $48 \mathrm{~h}$ had higher protein enrichment than just nitrogen addition at zero time.

\section{Inoculum Cell Size}

Each gram of substrate inoculated with $1.0 \times 10^{7}$ cells of Saccharomyces sp. IFO 1426 could get $16.11 \%$ protein of product in 3 days incubation. While the inoculum cell size increased to $1.0 \times 10^{8}$ cells, the product increased to $20.82 \%$ protein.

\section{DISCUSSION}

Solid-state fermentations are distinguished from submerged cultures by the fact that microbial growth and product formation occur at or near the surfaces of solid materials with low moisture content. ${ }^{10}$ Due to the low moisture content of substrate in solid-state fermentation, the bacteria contamination was not so severe, ${ }^{11}$ and the mi- crobes used in solid-state fermentation were limited in a large number of filamentous fungi, some yeasts, some actinomycetes, and few bacteria. ${ }^{4}$ The water-holding capacity of a sample could be used as an index of aerobiosis. ${ }^{6}$ The moisture content of sweet potato residue used in solid-state fermentation was $65-69 \%$ and lower than the water-holding capacity. The condition was suitable for the growth of aerobic microbes. The bulk density on a wetweight basis increased very sharply when the moisture content was higher than $62 \%$. This phenomenon was very similar to the adsorption isotherm of sweet potato residue. ${ }^{12}$ The water was less firmly bound when the moisture content was higher than $62 \%$. At the higher level of moisture content, the multilayer adsorption, the uptake into pores and capillary spaces, and mechanical entrapment of water were very important for microbial growth. ${ }^{13}$ In general, gas exchange depends on the bulk density and water-holding capacity of the substrate. The higher the bulk density and water-holding capacity, the slower the thermal diffusibility, oxygen transfer, and microbial transmission observed. ${ }^{6}$ During fermentation, the moisture content of substrate increased, which might be due to the production of metabolic water of fungi, as had been observed in the spawn of mushroom ${ }^{14}$ and sugar beet residue. ${ }^{15}$

Substrates traditionally used in solid-state fermentation are rice, wheat, millet, barley, corn, and soybeans. However, agricultural waste such as sweet potato residue might also be a good candidate because of its abundant supply and reasonable cost. Sweet potato residue contains $2.32 \%$ protein and $65.4 \%$ total carbohydrate and is, in itself, not a good source of protein for animal feeding. However, it could be enriched with protein by using amylolytic yeast by a solid-state fermentation process. In order to enrich the protein content from $4-6$ to $18-20 \%$, an additional $2.5 \%$

Table III. Effect of nitrogen supplement on protein enrichment. ${ }^{a}$

\begin{tabular}{|c|c|c|c|c|c|}
\hline \multirow[b]{2}{*}{ Item } & \multirow[b]{2}{*}{$\begin{array}{l}\text { Fermentation } \\
\text { time }(\mathrm{h})\end{array}$} & \multicolumn{2}{|c|}{$\left(\mathrm{NH}_{4}\right)_{2} \mathrm{SO}_{4}$-urea ratio $1: 1$} & \multicolumn{2}{|c|}{$\left(\mathrm{NH}_{4}\right)_{2} \mathrm{SO}_{4}$-urea ratio $2: 1$} \\
\hline & & $\begin{array}{l}\text { Added at time } \\
0 \text { with } 2.5 \%\end{array}$ & $\begin{array}{c}\text { Added at } 0,24 \text {, and } 48 \mathrm{~h} \\
\text { with } 1,1 \text {, and } 0.5 \%\end{array}$ & $\begin{array}{l}\text { Added at time } \\
0 \text { with } 2.5 \%\end{array}$ & $\begin{array}{c}\text { Added at } 0.24 \text {, and } 48 \mathrm{~h} \\
\text { with } 1.1, \text { and } 0.5 \%\end{array}$ \\
\hline \multirow{4}{*}{$\begin{array}{l}\text { Moisture } \\
\text { content }(\%)\end{array}$} & 0 & 62.37 & 60.42 & 62.28 & 59.93 \\
\hline & 24 & 60.93 & 58.36 & 62.01 & 59.05 \\
\hline & 48 & 59.75 & 61.38 & 59.83 & 60.26 \\
\hline & 72 & 61.43 & 65.81 & 62.41 & 66.06 \\
\hline \multirow{4}{*}{$\begin{array}{l}\text { Protein } \\
\quad \text { content }(\%)\end{array}$} & 0 & 5.93 & 5.54 & 5.43 & 5.46 \\
\hline & 24 & 8.14 & 9.84 & 8.51 & 9.03 \\
\hline & 48 & 11.16 & 12.61 & 11.25 & 12.49 \\
\hline & 72 & 15.07 & 17.99 & 15.05 & 16.84 \\
\hline \multirow[t]{4}{*}{$\mathrm{pH}$} & 0 & 4.9 & 4.9 & 4.9 & 4.9 \\
\hline & 24 & 4.5 & 4.5 & 4.5 & 4.3 \\
\hline & 48 & 4.3 & 4.1 & 4.3 & 4.1 \\
\hline & 72 & 4.1 & 3.9 & 3.9 & 3.7 \\
\hline \multirow{4}{*}{$\begin{array}{l}\text { Ash content } \\
\text { (\%) }\end{array}$} & 0 & 3.66 & 3.60 & 3.45 & 3.70 \\
\hline & 24 & 3.93 & 3.89 & 3.80 & 3.90 \\
\hline & 48 & 4.06 & 4.02 & 4.09 & 4.12 \\
\hline & 72 & 4.43 & 4.30 & 4.31 & 4.47 \\
\hline
\end{tabular}

\footnotetext{
${ }^{\text {a }}$ Fermentation conditions: Each gram of substrate inoculated with $4 \times 10^{7}$ cells Saccharomyces sp. IFO 1426 and incubated at $30^{\circ} \mathrm{C}$.
} 
nitrogen supplement is necessary theoretically. In this study, we found that the fractional supplement of nitrogen could result in a higher protein enrichment than supplement added only at zero time. These might be due to the maintenance of substrate $\mathrm{pH}$, lowering the nitrogen source inhibition, and increasing nitrogen efficiency.

Each gram of substrate with $1.0 \times 10^{7}-1.0 \times 10^{8}$ cells could produce a product containing $16.11-20.82 \%$ protein. The ORSTOM (Office de la Recherche Scientifique et Technique Outre-Mer, Paris) group indicated that the inoculum cell size of cassava starch in solid-state fermentation was $2.6 \times 10^{7}$ conidia of Aspergillus niger per gram of substrate. The starchy material containing $2-5 \%$ protein was transformed into enriched product containing 18$20 \%$ protein.

Saccharomyces does not produce the fungal toxin of $A s$ pergillus. ${ }^{16}$ Therefore, the commercial utility of protein enrichment of sweet potato residue with Saccharomyces sp. IFO 1426 by solid-state fermentation for animal feed appears to be promising.

The author thanks M. Y. Ling and J. Ting for their experimental assistance, K. T. Chung for his helpful discussions, and the National Science Council of the Republic of China for financial support.

\section{References}

1. J. C. Senéz, M. Raimbault and F. Deschamps, World Anim. Rev., 35, 36 (1980).

2. Economics and Planning Department, Custom Statistics-1984 Taiwan (Economics and Planning Department, Taiwan, 1986).

3. Department of Agriculture and Forest, in Taiwan Agricultural Yearbook-1984 (Provincial Government, Taiwan, 1985).

4. C. A. Grant, Y. M. Han and A. W. Anderson, Appl. Environ. Microbiol., 35, 549 (1978).

5. Y. M. Han and A. W. Anderson, Appl. Environ. Microbiol., 30, 930 (1975).

6. H. H. Wang, Proc. 2nd World Congr. Chem. Eng., 297 (1981).

7. L. D. Baver, Soil Physics, 3rd ed. (Wiley, New York, 1956), p. 178.

8. S. S. Yang, Natl. Sci. Counc. Month., 5, 478 (1977).

9. AVI, Food Analysis Laboratory Manual (AVI Publishing Company Inc., Westport, CT, 1975), pp. 85, 102.

10. R. E. Mudgett, in Manual of Industrial Microbiology and Biotechnology, A. L. Demain and N. A. Solomon, Ed. (American Society Microbiology, Washington, DC, 1986), p. 66.

11. E. Cannel and M. Moo-Young, Proc. Biochemis., 15, Jun/July, 2 (1980).

12. W. F. Chiu, Master's Thesis, Department of Agricultural Chemistry, National Taiwan University, Taipei, Taiwan, 1985, p. 38.

13. J. A. Troller and J. H. B. Christian, Water Activity and Food (Academic, New York, 1978), p. 5.

14. H. H. Wang, Mushroom Sci., 11, (Part 3), 93 (1981).

15. S. S. Yang, A. Durand and H. Blachére, J. Chin. Microbiol. Immunol., 19, 11 (1986)

16. G. Reed, Prescott \& Dunn's Industrial Microbiology, 4th ed. (AVI Publishing Company Inc., Westport, CT, 1982), p. 541. 